\title{
Britain draws up 'superleague' plan for leading research universities
}

London. Britain's Conservative government is planning to propose that a significant portion of its research budget is concentrated on a 'superleague' of nine or ten élite universities, almost 10 years after rejecting similar proposals as too politically sensitive.

Gillian Shephard, secretary of state for education and employment, will suggest the move to Sir Ron Dearing, a government education adviser who is conducting a review of higher education, according to government officials quoted in the British press.

The proposals will affect funding only from the three higher education funding councils, and not the research councils. Precise eligibility criteria for the superleague have not been revealed. But reports suggest that it will contain a fluctuating membership, based on research results rather than research income. Universities outside the league will be promoted to it if they reach the appropriate standard; those that do not perform adequately will be relegated.

Ten years ago, David Phillips, chairman of the now defunct Advisory Board for the Research Councils (ABRC), made similar suggestions in a report for the government of prime minister Margaret Thatcher (see Nature 328, 280; 1987 \& 330, 3; 1987). The ABRC report forecast continued dwindling research income, and proposed dividing up universities into three types: research-only,

The report was heavily criticized by the research and teaching, and teaching only the so-called 'RTX' formula.

scientific community. It was later rejected by Kenneth Baker, then education secretary. But Phillips, now a member of the House of Lords Select Committee on Science and Technology, says the report's adoption was inevitable, as the twin goals of funding both aspiring and élite research departments "required a lot of money, which was never going to come".

A spokeswoman for the education department points out that Shephard's reported statements are a continuation of the government's policy of concentrating research funds among a select number of departments pursuing 'world class' research. Already more than half of research funding from the Higher Education Funding Council for England goes to just 14 out of more than 100 university institutions.

The government's proposals have received a mixed reception, even among candidates for the superleague. Both supporters and critics acknowledge that they are designed to preserve the main citadels of research excellence at a time of sharp reductions in higher education funds, particularly for research equipment.

Alan Swanson, pro-rector for educational quality at Imperial College in London, says the suggested policy amounts to a belated recognition of the status quo. But David Livesey, secretary general of the faculties at the University of Cambridge - who supports selectivity at the departmental level warns that a superleague of universities

\section{BSE transmission data cause confusion}

London. The possibility that bovine spongiform encephalopathy (BSE) might be transmitted from cattle to sheep caused widespread concern and confusion last week. Franz Fischler, the European Union's Agricultural Commissioner, responded to what he described as "experimental evidence" by calling for a ban on various sheep and other ruminant tissues entering the food chain.

Research by the UK Institute of Animal Health has found that sheep selectively bred for resistance to natural scrapie, a disease in the same family as BSE, could still be infected by brain extracts from cattle suffering from BSE. Tissues recovered from one such sheep, out of six fed the infected material, induced a disease in mice with incubation periods and pathology closely resembling those caused by direct transmission of BSE from cattle to mice.
Although the pathways of the disease seem to be different in cattle and sheep only sheep showed infectivity in the spleen - the results have been taken to indicate a theoretical risk. Douglas Hogg, Britain's agriculture minister, says he is treating this with an "abundance of caution", recommending that sheep heads are destroyed in the same way as those of cattle.

Chris Bostock, head of molecular biology at the institute, describes the ban as a "sensible precaution". But he points out that, due to the similarities between BSE and scrapie, distinguishing between them when diagnosing sheep may be very difficult.

But concerns that scrapie in sheep could be masking BSE have come from "people speculating", says Francis Anthony, a spokesman for the British Veterinary Association. could erode Britain's research base.

Swanson points out that an effective superleague has been in operation for “donkey's years". Ideally, the government should provide more money for research, he says. But, "given that this is not going to happen, it is better to concentrate the limited funds on a few institutions."

But Derek Burke, former vice chancellor of the University of East Anglia - a leading research centre for environmental sciences and meteorology, but unlikely to become a member of the superleague - describes such a view as "arrogance" and "power play by the big guys". Burke points out that turn-

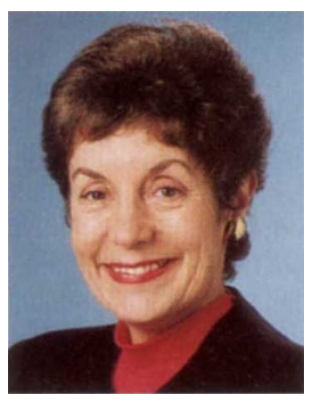

Shephard: continuing a policy of concentration. ing off the funding tap will wipe out important pockets of high quality research in lowertier universities.

Concentrating funds in a superleague could also harm the government's Technology Foresight exercise, he warns, through which the government funds research to enhance wealth creation and the quality of life. The success of the exercise, he says, relies on research excellence at smaller, newer universities.

The government's proposals are also opposed by the Association of University Teachers (AUT), the labour union which represents university staff. Paul Cottrell, assistant general secretary of the AUT, says that they effectively undermine the government's earlier decision to grant university status to all the former polytechnics.

The proposals mirror the conclusions of several independent reviews of postgraduate education funding. These include a review chaired by Martin Harris, vice chancellor of the University of Manchester (see Nature 381, 266; 1996), and a report from a working party chaired by David Harrison, Master of Selwyn College, Cambridge.

But Peter Collins, head of science advice at the Royal Society, points out that these reviews advocated concentrating funds at selected departments, rather than institutions. The study that inspired the ABRC report - a review of Earth science departments in 1987 chaired by Sir Ronald Oxburgh, former rector of Imperial College - also recommended the tiering of individual departments, rather than institutions.

Ehsan Masood 